\title{
Institutional Roles and Identity Construction of Applied Linguistics Faculty Involved in Interdisciplinary Collaborations for Multilingual Student Success
}

\section{Roumiana Ilieva, Amanda Wallace, E Valia Spiliotopoulos}

This article analyzes the academic identity constructions of applied linguists in the context of interdisciplinary collaborations as they seek to integrate language and content at the curricular core of an increasingly multilingual and multicultural university in Western Canada. The study draws on transcripts of audiotaped monthly meetings, framed as a professional learning community, where participants shared and discussed existing literature on interdisciplinary collaborations in support of multilingual student success, as well as their experiences with collaboration in the institution. In this qualitative study, data were analyzed thematically, and the themes that emerged suggest complex connections between institutional roles and professional identities with the changing roles of the participants in the institution interacting with the construction of their academic identities. Overall, we conceptualize these applied linguists as crossboundary academics who perform translational functions within the institution in negotiating their disciplinary knowledge with faculty across the disciplines. As such, they contribute to building capacity in working in a multilingual environment through their efforts to integrate language and content instruction jointly with their disciplinary colleagues.

Le présent article analyse les constructions d'identité académique d'un groupe de linguistes en linguistique appliquée dans le contexte de collaborations interdisciplinaires visant l'intégration de langue et de contenus dans le noyau curriculaire d'une université de plus en plus multilingue et multiculturelle de l'Ouest du Canada. L'étude s'appuie sur des transcriptions de réunions mensuelles enregistrées sur bande sonore au cours desquelles les participants, présentés comme une communauté d'apprentissage professionnelle, partageaient et discutaient de la littérature existante sur les collaborations interdisciplinaires en soutien $d u$ succès des étudiantes et étudiants multilingues, ainsi que de leurs expériences de collaboration au sein de l'établissement. Dans cette étude qualitative, les données ont fait l'objet d'une analyse thématique, et les thèmes qui ont émergé suggèrent l'existence de connexions complexes entre les rôles institutionnels et les identités professionnelles à mesure que l'évolution des rôles des participants au sein de l'établissement interagit avec la construction de leur identité académique. 
Globalement, nous conceptualisons ces linguistes en linguistique appliquée comme des universitaires transfrontaliers qui remplissent des fonctions translationnelles au sein de l'établissement en négociant leurs connaissances disciplinaires avec le corps professoral à travers les disciplines. Ce faisant, elles ou ils contribuent à l'accroissement de la capacité de travailler dans un environnement multilingue grâce à leurs efforts pour intégrer l'enseignement de langues et de contenus conjointement avec des collègues de diverses disciplines.

KEYWORDS: academic identity construction, interdisciplinary collaborations, institutional roles and academic identities of applied linguists

\section{Introduction}

Higher education in the 21st century is challenged by the forces of globalization and internationalization. Due to an increase in student mobility, higher education institutions (HEI) attract a more multicultural and multilingual student body. In response, multiple stakeholders in academic communities, including administration, faculty, and staff, are beginning to reassess effective educational practices (Arkoudis, Baik, \& Richardson, 2012; Murray, 2016a). Applied linguists (AL), with their expertise in languages and literacies, have a vital role in the internationalized university, including developing strategies and approaches to support multilingual student success. One such strategy involves integrating language and content instruction in the disciplines (Cammarata, 2016; Lin, 2016; Smit \& Dafouz, 2012).

A key challenge facing most Canadian HEIs wishing to integrate language and content as a pedagogical innovation is how to engage a critical mass of content faculty across the disciplines and diffuse the innovation beyond early adopters (Murray, 2016a; Rogers, 1995). This embedded model of support at the curricular core, supplementing English for Academic Purposes (EAP)-theme based courses and drop-in writing support, requires a culture shift, substantive support from academic leadership, and systematic faculty development and collaboration. Murray (2016a) made the case in the United Kingdom and Australia that embedding Academic Language and Literacy requires a strong awareness of institutional culture and politics and in-depth understanding of the unique needs of various faculties. Similar themes arose in literature on Content and Language Integrated Learning in Europe (Morton \& Llinares, 2017; Smit and Dafouz, 2012), Content-Based Instruction in the United States (Snow \& Brinton, 1988; Snow \& Brinton, 2017), and Immersion in Canada (Cammarata, 2016). This article contributes to scholarship addressing language and content integration in HEIs by focusing on a littleresearched area: ALs' professional roles and identity negotiations as they collaborate with disciplinary faculty in one Canadian university. 
An important impetus for this study stems from a call for ALs to have their voices heard in times of intensified internationalization (Millar, 2009). The focus is on ALs housed within an English Language Research Centre (ELRC) associated with a Faculty of Education in a Canadian HEI. This article draws on an inquiry into how ALs can support content faculty working with multilingual students. To gain an understanding of ALs' experiences, the study explores the professional development of ELRC faculty who meet monthly to discuss their work in relation to key concepts from scholarly readings. These ALs liaise with faculty across the disciplines collaborating on a variety of activities and interventions to support multilingual students. We report on data from the first stage of an ongoing study in a midsize comprehensive university in Western Canada, which we call Polyglot University (PU, a pseudonym). ${ }^{1}$ We address the following research questions:

Research Question 1: How do the accounts of these ALs' experiences in collaborative activities with content faculty impact their professional identities and roles within the institution?

Research Question 2: What can we learn from the professional development meetings of these ALs about their institutional roles and academic identity negotiations as they collaborate with content faculty?

\section{Literature Review}

\section{Professional Learning Communities}

To develop an understanding of the collaborative experiences of these ALs, we first consulted literature on collaboration in workplaces underscoring the notions of community of practice $(\mathrm{CoP})$ (Wenger, McDermott, \& Snyder, 2002) and a professional learning community (PLC) (DuFour \& Fullan, 2013). We conceptualized the ALs' monthly meetings as spaces for cultivating their professional $\mathrm{CoP}$ within the institution. CoP emphasizes the idea of people sharing an interest in a particular domain engaged in a process of learning collectively through regular interactions about their practices (Farnsworth, Kleanthous, \& Wenger-Trayner, 2016). By extension, PLCs entail a process of intensive reflection on instructional activities and outcomes to ensure student success. Given the tensions emerging from the accountability movement in North American HEIs (Hazelkorn, Coates, \& McCormick, 2018), discussions around student learning improvement go beyond data gathering for the purposes of obtaining accreditation. Although the accountability discourse addresses complex issues around performance and evidence of institutional effectiveness in a market-driven educational context, recent literature advocates a shared leadership model that assumes collective responsibility for analyzing assessment results, engaging in dialogue, and making key cur- 
riculum improvements collaboratively to support student learning (Austin \& Jones, 2018; DuFour \& Eaker, 1998; DuFour \& Fullan, 2013).

\section{Interdisciplinary Collaborations}

Another strand of consulted literature entails interdisciplinary collaborations. While there is growing research on language and subject specialist collaborations in K-12 (e.g., Arkoudis, 2006; Pawan \& Ortloff, 2011), a review of research on faculty collaborations suggests that interdisciplinary collaborations in HEIs are an underresearched topic (Ilieva \& Wallace, 2018; Smit \& Dafouz, 2012). We highlight Murray's (2016a) argument that disciplinary specialists and ALs should work together to address language and embed disciplinary academic literacy skills in content courses, with each bringing their expertise to identify disciplinary academic literacy practices. Existing literature on ALs and disciplinary specialists' collaborations in HEI in various contexts focuses on the nature of the interactions between interlocutors. Primarily, scholarship relates to negotiation and meaning-making, as discussed by Jacobs (2007), who conceptualizes collaboration as an unfolding of sorts wherein collaborators experience a process of "doing," "meaning-making," and "becoming." For Jacobs, collaborative partners discursively engage with one another in a "doing" process throughout their partnership as they navigate the experience of integrating academic literacies into the disciplines. The second process is "meaning-making," defined as "a cognitive [process flowing] directly from the process of discursive engagement with colleagues from different disciplines" working with each other to conceptualize academic literacies (p. 74). The third process, "becoming," refers to the academic identity construction of participants as they work toward a content- and language-integrated approach to teaching academic language and literacies. These three processes are dynamically interlinked across layers including relationships, conceptualizations of academic literacies, and academic identities.

Pawan and Green (2017) noted how building trust between partners is fundamental in collaborative interactions, as are the amount of time and various investments necessary for positive collaborations. In research on a university program set up for collaborations, Zappa-Hollman (2018) made a similar point about characteristics of positive partnerships, which include mutual respect, entering the collaboration on an equal footing, open-mindedness, common goals, and efficient planning. Moreover, elements related to personality, working style, and beliefs about teaching and learning also influence the effectiveness of collaborative partnerships (Perry \& Stewart, 2005). Goldstein, Campbell, and Cummings (1997) examined power dynamics in collaborative activities and found that language experts in an adjunct role

"may have difficulty with authority, with status and rank" in comparison with content faculty at the same institution (p. 23). 
Furthermore, in Canada, Weinberg, Knoerr, and Gohard-Redencovic (2016) highlighted that within immersion education in HEI, collaborations can reflect creativity and innovation in pedagogical activities across the disciplines when faculty members participate on their own volition. Knoerr (2018) also emphasized the need to formalize and make explicit a model for integrating language and content at the institution level. In the United States, Jimenez-Silva, Merritt, Rillero, and Kelley (2016) pointed to the importance of agreeing on terms, presenting a unified message, and advocating for developing a culture of change where every faculty member is perceived as language instructor. However, we have not been able to identify literature examining specifically the academic identity construction and negotiation of ALs as they engage in interdisciplinary collaborations. Therefore, this is the main focus of the research reported here. A major theoretical lens we use reflects current understandings of professional and/or academic identity ${ }^{2}$.

\section{Academic Identity}

There has been a recent increase in research on teacher identities and, particularly, language teacher identities (De Costa \& Norton, 2017; Varghese, Motha, Park, Reeves, \& Trent, 2016), but limited research on language and content faculty identity in HEIs. Likewise, "the current nature of higher education may be understood as a site of many identities-in-the-making" (Barnett \& Di Napoli, 2008, p. 4) as the globalization of higher education and technological advances continuously transform the work, roles, and relations of faculty, staff, and students. Consequently, academic identity development and identity negotiation are important aspects of the work of ALs collaborating on language and literacy matters with content faculty. Gee (2001) highlights the value of viewing "identity" as an important analytic tool for understanding educational settings and distinguishes between four perspectives on being "recognized as a certain 'kind of person' in a given context" (p. 100), two of which have a significant explanatory power for our study: I-identity (institutional identity), and D-identity (discourse identity). According to Gee, any identity enactment needs to be recognized by others to be meaningful and is ultimately dependent on discourse to sustain itself.

Several works focusing on academic identities in HEIs are particularly relevant for our study. Clarke et al. (2013) point out that "[f]aculty are living through a period of unprecedented change in higher education" (p. 15), and, in that context, "professional identity is a complex and multifaceted entity [with] many competing influences on teachers' roles and identities" (Clarke et al., p. 10). Taylor (2008) argues that "identities organize meaning while roles organize functions" (p. 29), and Delanty (2008) sees academic identity development as a "project" entailing positionality, performativity, situation in a context, and discursive construction (p.126). Academic identity relates to teaching and research activities that are commonly discipline-based, and it is 
"discipline-based cultures [that] are the primary source of faculty members' identity and expertise" (p. 7). Whitchurch (2008a, 2008b, 2009, 2013), whose main focus is on the identity development of professional staff (i.e., administrators, advisors, etc.) in HEIs, also points out that in times of globalization, academic identities are "expanding and becoming more heterogeneous" (Whitchurch, 2013, p. 115) because of the changing nature of academic work. The conceptual framework she develops for describing the emerging professional identities of staff in HEIs (2008a, 2008b) has relevance for academic identities and was used by Clarke et al. (2013) in their discussion of academics' identity transformations ${ }^{3}$.

The categories of professional identities that Whitchurch (2013) outlines are the following: bounded professionals, who perform clear and prescribed roles in the institution; cross-boundary professionals, who perform translational functions across the institution and contribute to institutional capacity building; unbounded professionals, who contribute to broad-based projects across a university setting; and blended professionals, who straddle professional and academic areas. The findings shared below draw on these categories to conceptualize the academic identity constructions of the ALs in our study. Whitchurch points as well to the in-between or "third" spaces occurring in HEIs, which are beyond established institutional structures and in which new roles and identities appear to be emerging "not necessarily recognized within existing organizational frameworks" (2013, p. 19). A second dimension of Whitchurch's framework represents four aspects of professional activity, that is, knowledges, relationships, legitimacies, and spaces, which impact professional identity development and transformation in the fluid "third" space of higher education characterized by indeterminacy and plurality in today's world (McAlpine, Jazvac-Martek, \& Gonsalves, 2008). Whitchurch's professional identity categories and associated aspects of professional activity guided us in the analysis of the data we share on our participants' academic identity construction.

We would like to briefly refer to literature on challenges that might accompany collaborations between ALs and disciplinary faculty resulting from entrenched disciplinary identities. As Duff (2017) states, "[m]any teachers' reluctance to engage with [issues around responsibilities to scaffold multilingual students' learning in content classrooms] stems from their identities (and expertise) as content teachers vs. language teachers. These professional identities may be deeply ingrained and fiercely protected" (p. 172). Within the limited HEIs' research on the identities of disciplinary faculty in relation to language and academic literacy matters, we highlight a study by Airey (2012) exploring the linguistic attitudes of physics lecturers in Sweden. Aptly titled "I don't teach language," the article points out that none of the 10 interviewed physics lecturers saw themselves as instructors of what the author calls "disciplinary" English. Similarly, in a survey conducted in the United States on the beliefs faculty hold on multilingual students and linguistically 
responsive instruction, Gallagher and Haan (2018) observe that "[disciplinary] faculty ... displayed deficit views regarding students' linguistic and academic abilities.... [and] many rejected the notion that language instruc-

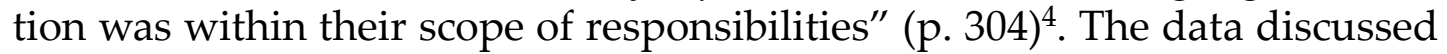
here confirm the presence of similar deficit views among some disciplinary faculty with whom the ALs collaborate. It is important to consider such views in light of the idea that "[p]eople's identities are in part forged in the kinds of knowledge practices that different disciplines engender" (Strathern, 2008, p. 11). The ALs' negotiations of such views through the roles they play in the institution via the newly established Centre they belong to form a significant part of the data discussed below.

\section{Research Context}

According to university statistics (Institutional Research and Planning, 2018a), PU's student body consists of more than 30,000 undergraduate students, $18 \%$ of whom are "international" with the assumption that, for most, English is an additional language. In addition, there are more than 5,000 graduate students, and roughly $30 \%$ of them are international. About $25 \%$ of the whole student population is learning in an additional language, and student selfreported data from an undergraduate survey suggest that more than $41 \%$ of students speak a language other than English at home (Institutional Research and Planning, 2018b).

The ELRC was established following a report prepared for the university Senate, which found that "Instructors at [PU] express concerns that inadequate language skills are hampering the academic success of some multilingual and EAL students" (English as an Additional Language Supports and Services, 2011, p. 2). This deficit perspective on multilingual students prompted ALs within its Faculty of Education to critique it and propose the establishment of a Centre, stating that there is

a need for a fundamental and significant shift at [PU] regarding English language services and support, moving from a deficit remediation perspective to an approach of developmental support.

EAL supports must move from the periphery to the curricular core and become central to learning at [PU]. (p. 5)

The ELRC was created in 2014 with the vision to promote and support inclusion and success for multilingual students across the disciplines. Some of the goals of the ELRC are directly tied to working with faculty across disciplines to redesign existing and co-construct new courses that integrate content and language instruction and help develop students' academic language needs within academic programs, as well as support disciplinary faculty in accessing research-based, best practices in teaching multilingual students. The first steps to working with faculties across the university began in the 
2015-2016 academic year, that is, only a year before the start of the study reported on here. Another focus of the ELRC is conducting empirical research and program evaluation to assess the effectiveness of various interventions/ programs that ELRC faculty help design. The Centre also offers coordination of language supports across the campus.

In conceptualizing ELRC, the ALs drew upon various models of second language development ranging from an adjunct "weak" support for multilingual students, adjunct "strong" support, integrated support, and an embedded model (see Jones, Bonanno, \& Scouller's [2009] Continuum of Support Mechanisms in Fenton-Smith \& Humphreys, 2015, p. 42) ${ }^{5}$. Integrated and embedded approaches have recently received much attention in the literature and are considered an effective way to connect skills and content (Chanock \& Horton, 2011; Harris \& Ashton, 2011; Jones, 2009). In these approaches, the academic language and literacy components become more visible with an explicit focus on language and literacy aspects relevant to content learning such that disciplinary instructors (and students) develop a greater awareness and knowledge of the academic discourse of their professional community (Harper, 2011; Melles, 2008; Roberts, 2008). The ALs at ELRC work with disciplinary faculty in various departments in implementing support structures along the continuum as per the departments' expectations. The goal is to move in the direction of embedded support as much as possible.

\section{Data Collection and Analysis}

The data are part of a study on the professional development of ALs associated with ELRC who liaise with faculties across PU. Conceptualized as a study of an inquiry-focused PLC (DuFour \& Fullan, 2013), this research analyzes the professional transformations of ALs resulting from the novel positions they begin to occupy in the institution. Data consist of transcripts of 16 audiotaped monthly meetings of about $1.5 \mathrm{hr}$ each where applied linguistics faculty and doctoral students (13 in total across 3 academic years, some 5-6 in any given year) share and discuss existing or pending literature on interdisciplinary collaborations in support of multilingual students in HEIs. The list of readings and topics at the PLC meetings (one reading being assigned at each) appears in the appendix.

All participants (i.e., both AL faculty and PhD students), with the exception of the principal investigator, engaged in interdisciplinary collaborations. Some collaborations involved team-teaching or curriculum redesign while others were drop-in support only, thus, they ranged from an adjunct weak to a fully embedded model of support. Most included the opportunity to sit in content classes and discuss disciplinary language and literacies with collaborators. Most participants were in the early stages of their academic careers, and most had not participated in collaborative activities prior to joining ELRC. The doctoral student research assistant for the project prepared 
a 2- to 3-page summary of the reading, and all had access to the full reading a week before each session. Usually, the meetings were attended by all ALs employed at ELRC in the academic year. All participants signed consent forms and were invited to participate in data analysis and dissemination. In the PLC, participants shared their thoughts on the reading, but also provided an update of their ELRC-affiliated activities to bridge ideas encountered in theory and research with practice. The questions that arose reflected an inquiry stance (Cochran-Smith \& Lytle, 2009) on one's professional practice and identity and involved conversations on successes and challenges in fostering interdisciplinary collaborations. The sessions developed organically in the sense that, sometimes, they started with the ALs' updates, and, sometimes, participants delved directly into the reading. The first reading was chosen by the principal investigator, and subsequent readings were guided by questions raised in the session preceding a specific reading discussion.

For this qualitative study, data were analyzed thematically (Saldaña, 2013). The process involved first and second cycle coding and writing analytic memos. The aim of the first stage was to develop understandings of the academic identity development of ALs through exploring their experiences in interdisciplinary collaborations and in a PLC. Whitchurch's framing provided a structure for the coding of factors impacting professional identities in HEI: knowledges, relations, legitimacies, and spaces. The focus is not on tracing how specific participants in the PLC responded to particular readings or negotiated their own academic identity, but rather on how the PLC as a space for making sense of experiences of interdisciplinary collaboration offers a glimpse into collectively negotiating identities as ALs. The emergent themes discussed below reflect the intricate connections between institutional roles and academic identities, with the changing roles of these ALs in the institution interacting with the construction of their academic identities.

\section{Findings}

We selected data to illustrate the collective role the participants play in institutional practices, such as applying research findings and theories into practice with the aim of bringing institutional change in working with multilingual students at PU. Given the focus on collective academic identity, the excerpts below - which come from seven of the 13 participants - are not attributed to specific ALs or contextualized further. Interdisciplinary collaborations are not commonly part of the institutional roles of ALs who are usually involved in preparing preservice teachers or in the direct instruction of English as an additional language (EAL) students or both. Thus, in entering into collaborations with other faculty from across the university, they are engaged in new academic roles and relationships. In this process, these ALs may experience challenges arising from existing institutional structures that are not flexible in accommodating their changing academic roles, and they have varied experi- 
ences in developing collaborations with disciplinary faculty. While the domains of knowledges, relations, legitimacies, and spaces are interrelated and at times overlapping, for clarity purposes, the data below will be presented under respective subheadings that most closely reflect a specific domain.

\section{Knowledges}

Whitchurch uses the term knowledges to indicate the necessity to integrate different sets of knowledge to operate efficiently in 21st-century HEIs. Disciplinary knowledge is tied to the roles one performs in a given institutional setting. As stated above, a commonly perceived role for ALs is as language specialists working primarily with multilingual students or with pre- or inservice teachers in developing ways to support multilingual students. In this study, one clear departure from this role is the transition of the participants to a more pronounced consulting and advisory role within PU. Deficiency views on multilingual students by some content faculty are common in some collaborative initiatives (cf. Gallagher \& Haan, 2018) the participants face:

The underlying notion I felt all the time was, "We would like somebody to deal with our non-native speakers. . . Fix their English and then send them back." I tried to explain that that would be ongoing and it's to be supported all the way through. (October 2016)

This comment also indicates the different perspectives and "knowledges" (Whitchurch, 2008a) that ALs and content faculty hold around the role of language in developing disciplinary knowledge, and ALs' insistence in the context of interdisciplinary collaborations on promoting a developmental approach in working with multilingual students at PU. The ALs are aware of the epistemological knowledge they bring to a collaborative endeavour, knowing "how language works, how long it takes," and how "context specific or genre based" it is, "things that people who haven't done applied linguistics don't know" (November 2017), which highlights the types of language development and academic literacies knowledge that many disciplinary faculty may be unaware of. Study participants are also very much aware of an important caveat: "the problem is different in different faculties" (March 2017).

As different faculties have different needs (Murray, 2016a), highlighting these differences is an important task for the ALs to ensure a holistic and discipline-specific stance in collaborating with content faculty. They need to focus on students' cognitive, emotional, and social well-being and on the language development, academic literacies, and content knowledge entanglements of preferred disciplinary genres within a discipline. Such a stance needs scaffolding-a pedagogical strategy in which the ALs are well grounded, thanks to their disciplinary knowledge and expertise:

it is really important that when you understand language proficiency development and ... are involved in language proficiency assess- 
ment issues in general, higher levels of language proficiency overlap with literacy skills.... it's not a problem of language per se and that's why when we only address it in one-off language courses ... it is not effective. It's that these skills are integrated with and interdependent with literacy skills, cognition, and disciplinary knowledge skills and attitudes. And, it's a holistic model. (PLC meeting, October 2016)

The ALs see their role very much as supporting the learning and professional development of content faculty and, thus, building institutional capacity in engaging with language matters by "getting some content faculty to recognize the importance that language plays in their discipline," which they themselves should integrate "within their teaching" (January 2017). The quote demonstrates the ALs' implicit knowledge of the importance that language plays in developing disciplinary knowledge and the ALs' conscious stance of being there to support faculty so that there is a shared responsibility in best practices to counter understandings of a focus on language as outside the scope of disciplinary faculty pedagogy (cf. Airey, 2012; Gallagher \& Haan, 2018).

Developing common new knowledge among these ALs at the meetings involves negotiating expectations around what the collaborative process entails, acknowledged in other studies (e.g., Zappa-Hollman, 2018). In that sense, collaboration is very much an unknown entity, "[i]t's an experiment, yeah!" (March 2017). This unknown entity is not only tied to negotiating understandings of disciplinary knowledge, but also crossing disciplinary languages to become a plurilingual academic:

it's a lot about speaking across languages. The language of the discipline and the linguist. ... it's interdisciplinary but it's plurilingual as well. The point is, do we try to develop a common language?

Are we trying to integrate understandings from both disciplines. . . . And how do you actually frame it in terms of the discourse within the discipline and this is where the applied linguist works through. (June 2017)

The ALs' use of the term plurilingual, associated with their disciplinary knowledge, makes sense of the kinds of epistemological stances they need to adopt to be able to converse in a meaningful way with their collaborators across disciplines.

\section{Relations}

An important aspect of building collaborative relations with content faculty, well documented in scholarly literature (e.g., Pawan \& Green, 2017; ZappaHollman, 2018), refers to the significance of investing time and developing trust for collaborations to have a chance to succeed. The quote below from 
one of the PLC meetings in the second term of this research is an example of these ALs' foundational work to perform an environmental scan to identify who potential champions might be and then to move on to establish collaborative projects:

[it's] important to note that September to December was really all about meeting stakeholders. Then, January was presenting an idea and getting buy-in. And, now ... we are ready to co-construct a plan. (February 2017)

At the same time, the question around negotiating these ALs' academic identities, together with building relations among themselves, as well as with others, given the nontraditional roles they play as part of the ELRC, is often discussed in the PLC meetings. See the exchange below between three participants in the second year of the research:

P1: What would this role of [the ELRC] be? Part of the role is to advocate, but part of the role ... is to provide that language development [for students] to help [them] meet that level of competence that is expected in [their future] profession, right?

P2: [The] ELRC has a huge role to play in professional development of [content] faculty. ... it's so much easier to do support for students on the level of, let me help you with your assignment, [in the Learning Support unit] they could help with it. But if you're not changing the mindset [of this student's professor].... I think it's broadly raising awareness across fields....

P3: Awareness raising. (November 2017)

Within the PLC, participants build on each other's ideas and develop shared knowledge about the discourse needed to establish a newly recognizable institutional identity (Gee, 2001) to bring about a culture of change (JimenezSilva et al., 2016). To that effect, the ALs also feel responsible for advocating for diversity within their collaborative activities, especially in recognizing multilingualism as an inherent aspect of the institution where "we are approaching this [work] from the perspective that this is a multilingual place and our strategies are for teaching a multilingual community" (October 2016).

By discursively constructing PU as a multilingual space, ELRC adds value beyond the customary work of teaching and learning centres, as this statement from the second year of the PLC suggests: "the drop-in support model ... that we have now at [Student Learning], ... it's a peer tutoring model" (February 2018). ALs recognize their unique relations and responsibilities within the institution because they are "at the curricular core." Whereas "[a Teaching and Learning unit] is like an 'outsider' . . to the course trying to advise/consult," the ALs are "on the ground ... doing that adaptation in 
collaboration with the faculty member and working with the students" (March 2017). As evident from this quote, these ALs are in the process of developing new relationships within a course-instructor-students dynamic. Power dynamics in relations with students are one novel aspect some of the ALs face. One PLC member wonders, for example, in the context of a teamteaching situation, "[a]re the students going to think I'm a TA ... Am I going to be put in this marginalized position?" (January 2017).

Regardless of such a challenge resulting from their changing role in the institution, ALs feel responsible for understanding and bridging disciplinary cultures in their collaborations with content faculty in a transdisciplinary space (cf. Jacobs, 2007) and, in the ongoing development of their academic identities, recognize the effort and time that it takes and the translation work (Whitchurch, 2008a, 2013) that is needed:

To build those relationships ... it's like going to a new country! . . . Learning about the culture and the history and the issues and the politics and the traditions [of the discipline]. And, we are coming in from a very different culture and country and academic tribe.

(March 2017)

The question of academic tribes has preoccupied scholars in HEIs for several decades and reflects the enduring power of disciplinary cultures. Indeed, in the context of academic relations, scholars recently acknowledged the significance of academic identities in how disciplinary practices are instantiated in a given setting (e.g., Trawler, Saunders, \& Bamber, 2012).

The relations of/in collaboration that ALs develop are constantly unfolding in the moment of on-the-ground, joint activity. Various metaphors arising in research on collaborations have attempted to capture this unfolding, including comparing the process to a volleyball game (Zappa-Hollman, 2018). The ALs in this study likened the dynamics of unfolding collaborative relations to dance:

One of the things [that has come up with my content faculty collaborator is] when I would intervene [in the classroom] as the language faculty and how that happens in a coherent and seamless fashion ... when it actually comes to team teaching... It's like a dance.

(January 2017)

This jointly choreographed dance cannot be rehearsed ahead of time: It really is like improvising ... You have to be on your toes the whole time and willing to jump in.... Like yesterday [a] student asked a question about an economic concept[,] "How is that in the text?". So then [my collaborator] gave an economics explanation and then I was able to say, "Oh, if you look at the article, you will see that it is implied in the third sentence". And we did that together.

(January 2017) 
As this quote highlights, "doing," "meaning-making," and "becoming" (Jacobs, 2007) are three interwoven processes inherent in this collaborative act. In the "doing" of the collaborative act in the classroom, the AL and the content faculty member are also involved in making meaning of each other's disciplines, and their academic identities are co-constructed as they work toward content and language integration in the moment, with these three processes "[feeding] into each other" (Jacobs, 2007, p. 74).

In continuing the theme of these ALs fostering novel relations, the idea that the ELRC is different from teaching and learning centres and other forms of student support is one that consistently appears in the data. Taking an active role at the curriculum core entails a responsibility to expand one's professional knowledge by learning about specific disciplinary discourses:

[To] learn the language of another community, as [ALs] it should be us, right? I am able to pick up concepts around ... human resources, organizational theory. I can read those ... language heavy [books], but other disciplines ... where the concepts are conveyed through symbols ... I don't know! (February 2017)

Therefore, in the meetings, the participants also discussed how they see the need to learn a new language - the language of the discipline of those they are collaborating with and challenges that are associated with this.

\section{Legitimacies}

The idea of legitimacies entails being recognized as an expert with valuable knowledge to impart. The process of learning disciplinary language entails not only developing new knowledge, but also developing an understanding of the concrete ways one can be relevant and legitimate in a disciplinary classroom:

What I am going to learn is discourse of economics ... I cannot tell a student "here is how you calculate the supply and demand shifts" . . . but I can tell them, "as a reader here is what I am getting from this. Here is how to put together a sentence that makes sense". . . that's going to be my way in rather than suddenly becoming an expert in economics in 13 weeks. (January 2017)

Thus, rather than attempting to become an expert in a particular disciplinary discourse, within their collaborations, these ALs find legitimacy in assisting students with gaining understanding of the linguistic aspects of the discourse of the discipline in which students are socialized (Harper, 2011).

Another key aspect of the ALs' new role represents their responsibility to research their practice in support of student learning in order to be perceived as legitimate: 
So, I guess the whole idea of [ELRC] having some sort of research and evaluation and impact assessment ..., was to demonstrate that we are actually adding value not only in terms of ... the professional development of these content faculty, but most importantly, . . to students. (January 2017)

This suggests that a key distinguishing factor for the ELRC is the idea that its members make evidence-based decisions in the interdisciplinary collaborative endeavour so that the work they do will ultimately positively affect student learning, something that participants had the opportunity to discuss in detail at the PLC meetings. This is a long and laborious process with many challenges. One challenge often referred to is how to negotiate existing institutional structures that reflect the lack of appreciation for interdisciplinary collaborations, because PU needs to "recognize the nature of the investment [while my collaborator], all this new course design, ... which is taking us hours, he is not really getting any ... compensation or course release for it" (February 2017).

Similarly, evaluating the ALs' collaborative work by using customary tenure and promotion guidelines based on individual performance is a challenge associated with ALs' legitimacy in a content classroom, as "from a structural perspective, dean's office doesn't know how my teaching will count" (June 2017). This is especially trying when "[ $t]$ here's a lot of rhetoric around community engagement, ... and interdisciplinary collaboration but the tenure and promotion process doesn't recognize these things" (March 2017). These challenges reflect working in a third space between well-established institutional structures (Whitchurch, 2013), which might impact the evaluation of the ALs' disciplinary expertise and legitimacy. To negotiate one's legitimacy within the institution, ALs, and sometimes their collaborative partners, need to engage in translation work by explicating at length the nature of their joint activities.

In addition, one aspect of some of the translation work ALs are involved in within their collaborative activities reflects different understandings of what communicating knowledge in one's discipline might entail and, thus, reaffirming one's academic legitimacy:

The feedback I got from the content instructor is, "Well, I still don't see a lot of work. Where is your content?" And, I'm like, "This is my content!" He is like, "But you haven't given me a PowerPoint". And, I'm like, "It's not about a PowerPoint, it's about my ideas."

(February 2017)

The question of ALs' legitimacy in collaborating with content faculty continues to be a topic in the PLC meetings. Speaking about the first class in a business course, a PLC participant co-taught in a previous term, the participant states, 
what I did in the first 10-minutes of the course was justify how my experience [has prepared me for this course] the. ... three main things were ... a) PhD in Writing; b) I helped develop this course . . ; c) and I worked at [another institution] for 3-years in [a] Business [faculty]. (January 2019)

The ALs' translation work is closely tied to the new institutional academic identity one performs with a question always lingering on one's mind: "[h]ow can I represent myself in a meaningful way to [my collaborators in another discipline]?" (January 2019).

\section{Professional Learning Communities as a Space to Construct New Identities}

The data so far demonstrate three aspects of professional/academic identity to which Whitchurch draws our attention: knowledges, relationships, and legitimacies. Whitchurch's fourth aspect, spaces, entails both physical space (e.g., an assessment centre) and space as a metaphor (e.g., an in-between space). Questions of physical space do not appear in our data, however, the question of symbolic space is quite evident in these PLC conversations, and we argue for the role of professional learning in constructing and reconstructing these ALs' academic identities. As mentioned, this research was conceptualized as an inquiry-focused study with members of the PLC sharing experiences and understandings around the collaborative activities they were part of in line with their new roles in liaising with content faculty. As discussed in the first meeting of the ALs,

These are meant to be professional development meetings ... collaborative inquiry. ... seeing this as a [space] in terms of figuring out. . . as professionals what are the kinds of challenges you face and what kinds of opportunities are out there and just move on in terms of really bringing some change to these institutions. (October 2016)

Thus, a major goal for this community is to work toward shifting institutional culture (Murray, 2016a) and bringing about change (Jimenez-Silva et al., 2016) with regard to language matters in HEIs by engaging in professional development conversations. These ideas are front and centre for the ALs and, consequently, a related purpose of the PLC meetings entails better understanding what collaborative endeavours might involve. Thus, the meetings focus on "working through our understandings and experiences of collaboration" (November 2017) by engaging in related scholarly literature and reflecting on one's collaborations. The meetings developed in an organic way where experiences and readings bounced off each other and led to enhanced understandings of one's professional practice. As one PLC member observed, "We often come back to, like, what is this all about really? I see [these] meetings as, that's the space where we do that. I call it the 'What does it all mean' 
meeting?" (February 2018). In other words, this is a place to make sense of one's work, and this purpose is reflected upon on several occasions. Thus, these meetings were experienced by the participants as a unique space:

To me, it is a very reflexive space ... to make myself be connected with some of the recent theories, also rethink about the activities that I do at the Centre and also be connected with the people who I am working with. . . . because we all meet every day but these [PLC] meetings create a condition where we can talk beyond our daily work-related duties and being reflexive about ... how our lives are being informed by the theories and how we can move forward. (January 2019)

Similarly, a very significant aspect of this study refers to the role of the PLC meetings in participants' negotiation and development of their academic identity. Thus, this was a space, where reflecting on their unique roles in the institution, these ALs saw themselves developing a common academic identity:

one of the things we all have in common is that we were willing to take the risk and assume the challenge ... to enter into this space... . and it is a vulnerable space as well, right? Which also kind of says . .. at our core we probably have ... a certain sense of legitimacy and confidence ... because ... with all due respect I know there were other roles [one could take on as AL].... very few people in education have entered this space [both of self-reflexivity and of collaborating in an interdisciplinary endeavour]... . [I]t takes a lot of courage. (January 2019)

As this quote attests, these were professional development meetings where participants drew on the community in making sense of their professional inquiries into their collaborative activities, a space where meaning was co-constructed and one could develop a cross-boundary identity and "be" interdisciplinary.

\section{Discussion}

The data presented in the Findings section address how the study participants experienced the domains of knowledges, relations, legitimacy, and space as interrelated and as impacting their academic identities. We concur with Delanty (2008) that academic identity development is a multifaceted "project" with social actors discursively constructing and performing their identities in different ways. A particularly important aspect of this process is associated with one's positionality in the institution, which "is also about the capacity to articulate one's voice and promote one's identity project" (Delanty, 2008, p. 129). It seems that the PLC meetings were a fertile space for 
these ALs to negotiate their positionality at PU. More specifically, this process seems to centre on the interplay between institutional roles and academic identities. As Delanty states,

many identities, and this is particularly true of academic identities, result from a creative engagement with institutional roles.... The changing institutional frameworks contain social spaces in which identities are being shaped and where many identity projects are emerging. (p. 133)

As identity work "is ongoing work" (Taylor, 2008, p. 27), one of continuous becoming, various takes on the role/identity interplay are important for the analysis we offer here. Taylor (2008) argues that "while roles involve accommodations with specific contexts, identities are ultimately 'internalizations' and, because of this, 'identities are stronger sources of meaning than roles'" (p. 29). In other literature, Beynon, Ilieva, and Dichupa (2001) reflect on the role-identity interplay of teachers of ethnic minority backgrounds working in the Canadian public-school system and take issue with Britzman's (1992) position on the matter, suggesting that

"role", which Britzman describes as impermeable and prescribed by normative institutional practices and ideologies, is, rather, potentially porous [as the] teachers of minority ancestry [in this study] infuse their roles with new dimensions that draw on their [ethnic and linguistic] identities.

In the context of these different understandings of the relation between institutional roles and professional identities, we would like to argue here that both the identities and roles of the ALs in this study could be viewed as "context-specific assemblages" (Taylor, 2008, p. 38). In this new third space, the roles they play in the institution, and the academic identities they make sense of in the space of the PLC, are entangled in ways where it is impossible to disassociate roles from identities, or assume directionality in the dynamic interaction between the participants' institutional role and academic identity. This complexity came to light in reflecting on the PLC impact on participants' depth of understanding around role, identity, and professional learning, and how the knowledges, relations, legitimacies, and spaces they experienced in their interdisciplinary collaborative activities were implicated in this.

\section{Concluding Thoughts}

The data presented here offer a glimpse into the process of academic identity construction that ALs undergo through their participation in a PLC; they document how they are making sense of their nontraditional roles in collaborating with content faculty in support of multilingual students to enact meaningful institutional change. The knowledges, relations, legitimacies, and 
spaces they reflect on attest to the ongoing nature of their academic identity "projects." It is also evident that as they engage in collaboration across the disciplines, ALs and content faculty come together in a "contact zone" where disciplinary "cultures meet, clash, and grapple with each other" (Pratt, 1999, p. 584). In this space, the ALs seem to be involved in building bridges across disciplines with established discourses, terminologies, and assumptions about learning and teaching through developing new knowledge (including learning new disciplinary languages), building novel relations and legitimacies, as well as imparting the disciplinary expertise with which they enter the collaborative endeavour. These spaces can be fraught with challenges, especially in relation to negotiating inflexible institutional structures. But these third spaces also offer opportunities and call for improvisation and creativity as content faculty and ALs collaborate to assure support for multilingual students' academic success. In all, within the context of this multilingual institution, one can observe the identity transformations of faculty who are part of the new ELRC at PU. Drawing on Whitchurch's framework on professional identities, we see these ALs as cross-boundary academics who perform translational functions within the institution. They translate their disciplinary knowledge to faculty across the disciplines and, thus, contribute to building capacity in a multilingual environment. As they embark on inquiring in their practices within a PLC, their ultimate goal is to affect student learning positively. A second stage in the study, involving interviews with content faculty who have collaborated with the ELRC, has started and will offer expanded understandings of the dynamics of interdisciplinary collaborations and their impact on student learning.

Several challenges in this work need to be recognized. While universities embrace internationalization primarily for economic purposes, the university structures are not set to support change in faculty's workloads within multilingual settings, thus, impeding collaborations across the disciplines. Therefore, we would like to suggest that this study calls for in-depth discussions of the need to support interdisciplinary collaboration in the multilingual HEIs of the 21st century by prioritizing content faculty incentives such as providing scholarly grants to redesign courses, or offering course releases for collaborative work, as well as establishing guidelines within the tenure and promotion process to recognize and value interdisciplinary work (Coburn \& Stein, 2010). Such initiatives could enhance collaborative endeavours to support the academic success of all students in the multilingual spaces that Canadian universities have become.

\section{Notes}

1. For anonymity purposes, the pseudonym Polyglot University (PU) is also used in sources published by the institution cited herein. 
2. We will use the term "academic identity" in our analysis to address faculty members' identity construction. However, in literature where the term "professional identity" has been used to discuss the identity constructions of teachers or instructors, we will keep the term used by the authors we reference. A special case within this article is the work of Whitchurch whose main focus is on the identities of "professionals" in higher education institutions (HEI) in the United Kingdom, whom we would normally call "staff" in Canadian HEIs. When we refer to Whitchurch's work on the identity of staff and administrators, we will use the term "professional identity." Recent literature (e.g., Clarke, Hyde, \& Drennan, 2013) has taken up Whitchurch's theorizing to discuss the academic identities of faculty, and, as such, we also make use of her work, and when discussing faculty identities, we will use the term "academic identity."

3. Whitchurch's work has been taken up, to some extent, with regard to English for Academic Purposes (EAP) units in HEIs and in directions that are not of specific relevance for the research described here. As the data shared here refer to applied linguists (AL) who are members of a Faculty of Education engaged in various forms of collaboration with disciplinary faculty, our study participants differ from those discussed in the works of Hadley (2015) and MacDonald (2016), so we have found Whitchurch's conceptualizations helpful in other ways.

4. The idea that views instructors hold are tied to the identities they enact in classrooms has been asserted in language teacher identity scholarship since the early 2000s (e.g., Varghese, Morgan, Johnston, \& Johnson, 2005).

5. An "adjunct" support mechanism is defined as one developed separately from the discipline content and added on to it outside the time-tabled course. In recent years, there has been a tendency to move away from generic adjunct "weak" support characterized by EAP/EGAP (English for General Academic Purposes) type courses that take a more study-skills approach to language and literacy support (Hyland, 2011; Wingate, Andon, \& Cogo, 2011). There is much research documenting the effectiveness of discipline-specific adjunct "strong" models typically created to support the language and literacy aspects of a specific content course. Integrated and embedded approaches located further along the continuum are often described as "built-in" because the academic language and learning are delivered concurrently with the content within the time-tabled content course. 


\section{The Authors}

Roumiana llieva is an associate professor in additional language education at the Faculty of Education at Simon Fraser University. Her research interests include internationalization of higher education, language teacher identities and agency, academic identity construction, interdisciplinary collaborations for multilingual student success, migration, and integration.

Amanda Wallace is a doctoral candidate in the Languages, Cultures, and Literacies program at Simon Fraser University. Prior to her doctoral studies, she was an assistant teaching professor in the College English Program at Seoul National University. Her research interests include English as an additional language, academic literacies, content and language integrated learning, and interdisciplinary collaborations.

Valia Spiliotopoulos is a tenure-track Instructor in the Department of Language and Literacy Education in the Faculty of Education at the University of British Columbia. Her research examines how content-based language learning approaches and language policy can impact bi/multilingualism and academic success. She has also published in the areas of intercultural competence, academic writing, and educational innovation at the postsecondary level. She has assumed faculty-level and university-wide leadership roles in teacher and faculty development programs and initiatives, and has taught English for Academic Purposes, academic writing, and French in B.C., Ontario, and Quebec.

\section{References}

Airey, J. (2012). "I don't teach language": The linguistic attitudes of physics lecturers in Sweden. AILA Review, 25(1), 64-79. https://doi.org/10.1075/aila.25.05air

Arkoudis, S. (2006). Negotiating the rough ground between ESL and mainstream teachers. International Journal of Bilingual Education and Bilingualism, 9(4), 415-433. https://doi. org $/ 10.2167 /$ beb337.0

Arkoudis, S., Baik, C., \& Richardson, S. (2012). English language standards in higher education: From entry to exit. Camberwell: Acer Press.

Austin, I., \& Jones, G. (2018). Emerging trends in higher education governance: Reflecting on performance, accountability and transparency. In E. Hazelkorn, H. Coates, \& A. C. McCormick, Research handbook on quality, performance and accountability in higher education. Edward Elgar Publishing.

Barnett, R., \& Di Napoli, R. (Eds.). (2008). Changing identities in higher education: Voicing perspectives. London, UK: Routledge.

Beynon, J., Ilieva, R., \& Dichupa, M. (2001). Teachers of Chinese ancestry: Interaction of identities and professional roles. Teaching Education, 12(2), 131-149.

Cammarata, L. (Ed.). (2016). Content-based foreign language teaching: Curriculum and pedagogy for developing advanced thinking and literacy skills. New York, NY: Routledge.

Canagarajah, S. (2006). Changing communicative needs, revised assessment objectives: Testing English as an international language. Language Assessment Quarterly, 3(3), 229-242. https:// doi.org/10.1207/s15434311laq0303_1

Canagarajah, S. (2018). Materializing "competence": Perspectives from international STEM scholars. The Modern Language Journal, 102(2), 268-291. https://doi-org.proxy.lib.sfu.ca/10.1111/ modl.12464

Chanock, K., \& Horton, C. (2011, November 24-25). Strange bedfellows: Embedding development of skills in discipline curricula. Paper presented at the Tenth Biennial Conference of the Association for Academic Language and Learning (pp. 23-25). Adelaide, Australia.

Clarke, M., Hyde, A., \& Drennan, J. (2013). Professional identity in higher education. In M. Kehm \& U. Teichler (Eds.), The academic profession in Europe: New tasks and new challenges (pp. 7-21). Dordrecht, Netherlands: Springer Science \& Business Media. doi:10.1007/978-94-007-4614-5

Coburn, C. E., \& Stein, M. K. (2010). Research and practice in education: Building alliances, bridging the divide. New York, NY: Rowman \& Littlefield Publishers. 
Cochran-Smith, M., \& Lytle, S. L. (2009). Inquiry as stance: Practitioner research for the next generation. New York, NY: Teachers College Press.

Dafouz, E., and Smit, U. (2016). Towards a dynamic conceptual framework for English-medium education in multilingual university settings. Applied Linguistics, 37(3), 397-415. https://doi. org/10.1093/applin/amu034

De Costa, P., \& Norton, B. (2017). Introduction: Identity, transdisciplinarity, and the good language teacher. The Modern Language Journal, 101(S1), 3-14. https://doi.org/10.1111/modl.12368

Delanty, G. (2008). Academic identities and institutional change. In R. Barnett \& R. Di Napoli (Eds.), Changing identities in higher education: Voicing perspectives (pp. 124-133). London, UK: Routledge.

Duff, P. (2017). Language teacher identities and socialization. In G. Barkhuizen (Ed.), Reflections on language teacher identity research (pp. 170-175). London, UK: Routledge.

DuFour, R., \& Eaker, R. (1998). Professional learning communities at work: Best practices for enhancing student achievement. Alexandria, VA: Association for Supervision and Curriculum Development.

DuFour, R., \& Fullan, M. (2013). Cultures built to last: Systemic PLCs at work ${ }^{\mathrm{TM}}$. Bloomington, IN: Solution Tree Press.

English as an Additional Language Supports and Services at PU: Review and Recommendations. (2011). Polyglot University, Canada.

Farnsworth, V., Kleanthous, I., \& Wenger-Trayner, E. (2016). Communities of Practice as a social theory of learning: A conversation with Etienne Wenger. British Journal of Educational Studies, 64(2), 139-160. https://doi.org/10.1080/00071005.2015.1133799

Fenton-Smith, B., \& Humphreys, P. (2015) Language specialists' views on academic language and learning support mechanisms for EAL postgraduate coursework students: The case for adjunct tutorials. Journal of English for Academic Purposes, 20, 40-55. https://doi.org/10.1016/j. jeap.2015.05.001

Gallagher, C. E., \& Haan, J. E. (2018). University faculty beliefs about emergent multilinguals and linguistically responsive instruction. TESOL Quarterly, 52(2), 304-330. https://doi. org/10.1002/tesq.399

Garson, K., Bourassa, E., and Odgers, T. (2016). Interculturalising the curriculum: Faculty professional development. Intercultural Education, 27(5), 457-473. http://dx.doi.org/10.1080/14675 986.2016.1240506

Gee, J. (2001). Identity as an analytic lens for research in education. Review of Research in Education, 25, 99-125. http://www.jstor.org/stable/1167322

Goldstein, L., Campbell, C., \& Cummings, M. (1997). Smiling through the turbulence: The flight attendant syndrome and writing instructor status in the adjunct model. In M. A. Snow \& D. Brinton (Eds.), The content-based classroom: Perspectives on integrating language and content (pp. 331-339). White Plains, NY: Longman.

Hadley, G. (2015). English for academic purposes in neoliberal universities: A critical grounded theory. New York, NY: Springer.

Harper, R. (2011, November 23-25). Beyond transition: Mapping the staged development of academic literacies at university. Paper presented at the Tenth Biennial Conference of the Association for Academic Language and Learning. University of Adelaide. https://core.ac.uk/download/ pdf/143901792.pdf

Harris, A., \& Ashton, J. (2011). Embedding and integrating academic skills: An innovative approach. Journal of Academic Language \& Learning, 5(2), 73-87. Retrieved from http://journal. aall.org.au/index.php/jall/article/view/158/110

Hazelkorn, E., Coates, H., \& McCormick, A. C. (2018). Research handbook on quality, performance and accountability in higher education. Edward Elgar Publishing.

Hyland, K. (2011). Writing in the university: Education, knowledge and reputation. Language Teaching, 46(1), 53-70. http://dx.doi.org/10.1017/ S0261444811000036 
Ilieva, R., \& Wallace, A. (2018, June). Conceptualizing English-as-a-dominant language contexts within the internationalization of higher education in dialogue with Dafouz and Smit's ROAD-MAPPING Framework. Conference presentation. 22nd Sociolinguistics Symposium. Auckland, New Zealand.

Institutional Research and Planning (2018a). Fall international student report. Polyglot University, Canada.

Institutional Research and Planning. (2018b). 2018 Undergraduate student survey: Preliminary report. Polyglot University, Canada.

Jacobs, C. (2007). Towards a critical understanding of the teaching of discipline-specific academic literacies: Making the tacit explicit. Journal of Education, 41, 59-82. Retrieved from https:// journals.co.za/docserver/fulltext/joe/41/1/24.pdf?expires=1552344476\&id=id\&accname=gue st\&checksum $=$ C82391691B48F52831AFEB1141836F8F

Jacobs, C. (2010). Collaboration as pedagogy: Consequences and implications for partnerships between communication and disciplinary specialists. Southern African Linguistics and Applied Language Studies, 28(3), pp. 227-237. http://dx.doi.org/10.2989/16073614.2010.545025

Jimenez-Silva, M., Merritt, J., Rillero, P., \& Kelley, M. F. (2016). Working together to prepare teachers of science and language: Examining the value of collaboration among science and language faculty. Electronic Journal of Science Education, 20(3). Retrieved from https://files.eric. ed.gov/fulltext/EJ1188093.pdf

Jones, A. (2009). Redisciplining generic attributes: The disciplinary context in focus. Studies in Higher Education, 34(1), 85-100. http://dx.doi.org/10.1080/ 03075070802602018.

Knoerr, H. (2018). Collaboration between language and content instructors: Keystone and weak link of content and language integration environments. In H. Knoerr, A. Weinberg, C. E. Buchanan (Eds.), Current issues in university immersion. Montréal: Groupe de recherche en immersion au niveau universitaire, University of Ottawa.

Lin, A. M. Y. (2016). Language across the curriculum \& CLIL in English as an additional language (EAL) contexts: Theory and practice. Singapore: Springer.

MacDonald, J. (2016). The margins as third space: EAP teacher professionalism in Canadian universities. TESL Canada Journal, 34(11), 106-116. https://doi.org/10.18806/tesl.v34i1.1258

McAlpine, L., Jazvac-Martek, M., \& Gonsalves, A. (2008). The question of identity: Negotiating roles and voices in evolving academic systems. In R. Barnett \& R. Di Napoli (Eds.), Changing identities in higher education: Voicing perspectives (pp. 113-123). London, UK: Routledge.

Melles, G. (2008). Teaching critical appraisal skills to postgraduate English as a second language, engineering students. Australasian Journal of Engineering Education, 14(2), 23-32. https://doi. org/10.1080/22054952.2008.11464010

Millar, G. (2009). Working with international students: Applied linguistics and the art of inclusive teaching. TESOL in Context, S2, 1-12. Retrieved from http://www.tesol.org.au/files/ files/91_Millar.pdf

Morton, T., \& Llinares, A. (2017). Content and Language Integrated Learning (CLIL): Type of programme or pedagogical model? In A. Llinares \& T. Morton (Eds.), Applied linguistics perspectives on CLIL (pp. 1-13). Netherlands: John Benjamins.

Murray, N. (2016a). Standards of English in higher education: Issues, challenges and strategies. Cambridge, UK: Cambridge University Press.

Murray, N. (2016b). An academic literacies argument for decentralizing EAP provision. ELT Journal, 70(4), 435-443. http://doi.org/10.1093/elt/ccw030\%20

Murray, N., \& Nallaya, S. (2014). Embedding academic literacies in university programme curricula: A case study. Studies in Higher Education, 41(7), 1296-1312. https://doi.org/10.1080/0 3075079.2014.981150

Paretti, M. (2011). Interdisciplinarity as a lens for theorizing language/content partnerships. Across the Disciplines, 8(3). Retrieved from http://wac.colostate.edu/atd/clil/paretti.cfm

Pawan, F., \& Green, M. C. S. (2017). In trust, we collaborate: ESL and content-area teaching working together in content-based language instruction. In M. A. Snow \& D. Brinton (Eds.), 
The content-based classroom: New perspectives on integrating language and content (2nd ed.), (pp. 323-337). Ann Arbor: University of Michigan Press.

Pawan, F., \& Ortloff, J. H. (2011). Sustaining collaboration: English-as-a-second-language, and content-area teachers. Teaching and Teacher Education, 27(2), 463-471. https://doi.org/10.1016/j. tate.2010.09.016

Perry, B., \& Stewart, T. (2005). Insights into effective partnership in interdisciplinary team teaching. System, 33(4), 563-573. https://doi.org/10.1016/j.system.2005.01.006

Pratt, M. L. (1999). Arts in the contact zone. In D. Bartholomae \& A. Petrosky (Eds.), Ways of reading: An anthology for writers (5th ed.), (pp. 582-596). Boston: Bedford/St. Martins.

Read, J. (2013). Issues in post-entry language assessment in English-medium universities. Language Teaching, 48(2), 217-234. https://doi.org/10.1017/S0261444813000190

Roberts, M. (2008, December 2-5). Assessment and diversity: A collaborative project between academic staff and learning support staff in a university. Paper presented at the ISANA International Education Conference, Auckland, New Zealand. http://isana.proceedings.com.au/docs/2008/ paper_Roberts.pdf

Rogers, E. (1995). Diffusion of innovations (5th ed.). New York, NY: Free Press.

Saldaña, J. (2013). The coding manual for qualitative researchers (2nd ed.). London, UK: Sage.

Smit, U., \& Dafouz, E. (2012). Integrating content and language in higher education: An introduction to English-medium policies, conceptual issues and research practices across Europe. AILA Review, 25(1), 1-12. https://doi.org/10.1075/aila.25

Snow, M., \& Brinton, D. (1988). Content-based language instruction: Investigating the effectiveness of the adjunct model. TESOL Quarterly, 22(4), 553-574.

Snow, M., \& Brinton, D. (Eds.). (2017). The content-based classroom: New perspectives on integrating language and content (2nd ed.). Ann Arbor: University of Michigan Press.

Strathern, M. (2008). Preamble: Knowledge identities. In R. Barnett \& R. Di Napoli (Eds.), Changing identities in higher education: Voicing perspectives (pp. 9-20). London, UK: Routledge.

Taylor, P. (2008). Being an academic today. In R. Barnett \& R. Di Napoli (Eds.), Changing identities in higher education: Voicing perspectives (pp. 28-39). London, UK: Routledge.

Trowler, P., Saunders, M., and Bamber, R. (Eds.) (2012). Tribes and territories in the 21st-century: Rethinking the significance of disciplines in higher education. London: Routledge.

Varghese, M., Morgan, B., Johnston, B., \& Johnson, K. (2005). Theorizing language teacher identity: Three perspectives and beyond. Journal of Language, Identity, and Education, 4, 21-44.

Varghese, M. M., Motha, S., Park, G., Reeves, J., \& Trent, J. (Guest Eds.). (2016). Language teacher identity in (multi)lingual educational contexts. TESOL Quarterly, 50, 541-783. Retrieved from https://onlinelibrary.wiley.com/toc/15457249/50/3

Waye, L. (2010). Learning how to work with instructors of international EAL graduate students to better support their students' development of academic writing (Unpublished doctoral dissertation). University of Victoria, British Columbia, Canada.

Weinberg, A. H., Knoerr, H., \& Gohard-Redencovic, A. (2016). L'immersion française à l'université: Politiques et pédagogies. Ottawa, Ontario, Canada: Les Presses de l'Université d'Ottawa.

Wenger, E., McDermott, R., Snyder, W. M. (2002). Cultivating communities of practice: A guide to managing knowledge. Boston, MA: Harvard Business Review Press.

Whitchurch, C. (2008a). Beyond administration and management: Changing professional identities in UK higher education. In R. Barnett \& R. Di Napoli (Eds.), Changing identities in higher education: Voicing perspectives (pp. 69-88). London, UK: Routledge.

Whitchurch, C. (2008b). Shifting identities and blurring boundaries: The emergence of third space professionals in UK higher education. Higher Education Quarterly, 62(4): 377-396. https://doi.org/10.1111/j.1468-2273.2008.00387.x

Whitchurch, C. (2009). The rise of the blended professional in higher education: A comparison between the United Kingdom, Australia and the United States. Higher Education, 58(3), 407-418. https://doi.org/10.1007/s10734-009-9202-4 
Whitchurch, C. (2013). Reconstructing identities in higher education: The rise of "third space" professionals. London, UK: Routledge.

Wingate, U., Andon, N., \& Cogo, A. (2011). Embedding academic writing instruction into subject teaching: A case study. Active Learning in Higher Education, 12(1), 69-81. https://doi. org/10.1177/1469787410387814

Zappa-Hollman, S. (2018). Collaboration between language and content university instructors: Factors and indicators of positive partnerships. International Journal of Bilingual Education and Bilingualism, 21(5), 591-606. https://doi.org/10.1080/13670050.2018.1491946

\section{Appendix}

Table A1

Year 1 Dates, Topics, and Readings for PLC Meetings

\begin{tabular}{|c|c|c|}
\hline Date & Topics & Reading(s) \\
\hline October 2016 & First PLC meeting & None \\
\hline January 2017 & $\begin{array}{l}\text { Collaboration between science faculty members } \\
\text { and language faculty members; teacher education; } \\
\text { content-based SLA }\end{array}$ & $\begin{array}{l}\text { Jimenez-Silva, Merritt, Rillero, \& Kelly, } \\
2016\end{array}$ \\
\hline February 2017 & Academic literacies; decentralized EAP provision & Murray, 2016b \\
\hline March 2017a & $\begin{array}{l}\text { English language proficiency; embedding literacy } \\
\text { and language support at curricular core }\end{array}$ & Murray \& Nallaya, 2014 \\
\hline March 2017b & $\begin{array}{l}\text { EAL graduate students; academic writing; instructor } \\
\text { professional development }\end{array}$ & Waye, 2010 \\
\hline June 2017 & $\begin{array}{l}\text { Theorizing language/content partnerships; } \\
\text { interdisciplinary collaboration }\end{array}$ & Paretti, 2011 \\
\hline
\end{tabular}

Table A2

Year 2 Dates, Topics, and Readings for PLC Meetings

\begin{tabular}{lll}
\hline $\begin{array}{l}\text { Date } \\
\text { October 2017 }\end{array}$ & $\begin{array}{l}\text { Topics } \\
\text { Academic literacies; HE; collaborations, language/ } \\
\text { disciplinary experts }\end{array}$ & $\begin{array}{l}\text { Reading(s) } \\
\text { Jacobs, 2007 }\end{array}$ \\
November 2017 & $\begin{array}{l}\text { Conceptualizing EMl in HE; ROAD-MAPPING } \\
\text { framework }\end{array}$ & Dafouz \& Smit, 2016 \\
December 2017 & $\begin{array}{l}\text { Faculty development; interculturalization; } \\
\text { internationalization; inclusive pedagogy }\end{array}$ & Garson, Bourassa, \& Odgers, 2016 \\
February 2018a & $\begin{array}{l}\text { Assessment; English proficiency; standardized tests; } \\
\text { communication skills }\end{array}$ & Canagarajah, 2006 \\
February 2018b & $\begin{array}{l}\text { Academic language and literacies; EAL; adjunct } \\
\text { tutorials } \\
\text { Academic language and literacies; credit-bearing }\end{array}$ & Fenton-Smith \& Humphreys, 2015 \\
April 2018 & $\begin{array}{l}\text { Fenton-Smith, Humphreys, \& } \\
\text { Walkinshaw, 2018 }\end{array}$
\end{tabular}




\begin{tabular}{|c|c|c|}
\hline Date & Topics & Reading(s) \\
\hline May 2018 & $\begin{array}{l}\text { EAP, instructor collaboration, disciplinary instructors, } \\
\text { language instructors, positive partnerships }\end{array}$ & Zappa-Holman, 2018 \\
\hline \multirow{2}{*}{\multicolumn{3}{|c|}{$\begin{array}{c}\text { Table A3 } \\
\text { Year } 3 \text { Dates, Topics, and Readings for PLC Meetings }\end{array}$}} \\
\hline & & \\
\hline Date & Topics & Reading(s) \\
\hline October 2018 & $\begin{array}{l}\text { Content and language integrated learning; SLA, } \\
\text { SFL; Discourse analysis; Sociolinguistics }\end{array}$ & Morton \& Llinares, 2017 \\
\hline November 2018 & $\begin{array}{l}\text { English language proficiency; assessment; post- } \\
\text { entry; HE }\end{array}$ & Read, 2013 \\
\hline January 2019 & $\begin{array}{l}\text { STEM; materiality; embodiment; language } \\
\text { competence }\end{array}$ & Canagarajah, 2018 \\
\hline February 2019 & Professional identities; HE; third space & Whitchurch, 2008 \\
\hline April 2019 & $\begin{array}{l}\text { HE; EAL provision; academic literacies; } \\
\text { collaboration; funding }\end{array}$ & Murray, 2016a \\
\hline \multirow[t]{2}{*}{ May 2019} & $\begin{array}{l}\mathrm{HE} \text {; collaboration; language and content faculty } \\
\text { members; pedagogy }\end{array}$ & $\begin{array}{l}\text { Jacobs, 2010; Marshall, Conana, } \\
\text { Maclon, Herbert, \& Volkwyn, } 2011\end{array}$ \\
\hline & $\begin{array}{l}\text { Academic literacies; collaborative partnerships; } \\
\text { Disciplinary discourse; physics }\end{array}$ & \\
\hline
\end{tabular}

Note. PLC = professional learning community; SLA = second language acquisition; SFL = systemic functional linguistics; $\mathrm{HE}=$ higher education; $\mathrm{EMI}=$ English as a medium of instruction; $\mathrm{STEM}=$ science, technology, engineering, and mathematics; EAL = English as an additional language. 